\title{
A Study of Repayment of Education Loan in Tamil Nadu
}

\author{
R.Lavanya ${ }^{1}$, Dr.S.Ramachandran ${ }^{2}$ \\ Research Scholar, Bharath University, Chennai ${ }^{l}$, \\ Research supervisor, AMET University, Chennai ${ }^{2}$
}

\begin{abstract}
Educational loan is now a days is gaining more popularity among the students those who want to pursue for higher education. In which Tamil Nadu is playing major role by proving the Education loan through various banks and helping the deserving students. This paper is basically to known about how the repayment is done and procedures for availing it.
\end{abstract}

Keywords: Education loan, Tamil Nadu, India

\section{Introduction}

Education loan is a popular method of funding loans to the young aspirants who wishes to pursue higher education in India and as well as in abroad. This scheme provides financial support to a meritorious student or a deserving student in order to proceed with their higher education with affordable terms and conditions.

\section{Education Loan In India}

In India, around 704 million populations are of age group between 18-30 years, with combined ratios. The education loan is given in order to improve the economic status of the country and in turn to improve the wealth distribution. For every rise of $1 \%$ in GDP, demand for education loan rises to $3 \%$. There are totally 21 Public Sector Banks (PSB) in India which provides educational loan.

Chart 1 explains What is education loan?

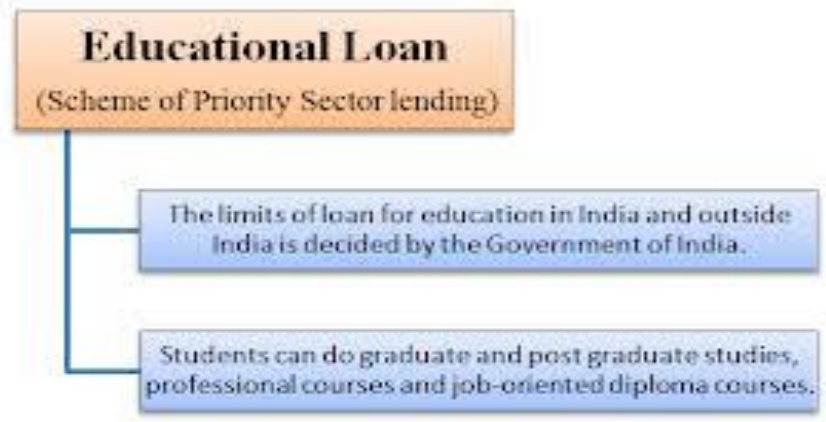

\section{Education Loan In Tamil Nadu}

The main focus of education loan is to provide financial assistance for needy and deserving students with good academic performance and in order to support students for doing higher study, professional education, and technical education in India and abroad. In this the researcher explains about the education loan in Tamil Nadu with a list of banks in Tamil Nadu and maximum loan amount given, its interest rates and lots of other factors. As on 30th Sep 2012, the outstanding amount in educational loan is Rs.8841 crores (within Tamil Nadu)

Table 1 explains Eligibility criteria to get a loan from Tamil Nadu Government

\begin{tabular}{|l|}
\hline Concerned Department:BC, MBC \& Minorities Welfare Department \\
\hline Concerned District:All Districts \\
\hline Organisation Name:Backward Classes Welfare Directorate \\
\hline Scheme Details \\
\hline Title / Name:Education Loan \\
\hline Associated Scheme: \\
\hline Sponsored By:State \\
\hline Funding Pattern: \\
\hline Beneficiaries:BC/MBC \\
\hline Benefits Types:Education Benefits \\
\hline Eligibility criteria \\
\hline
\end{tabular}




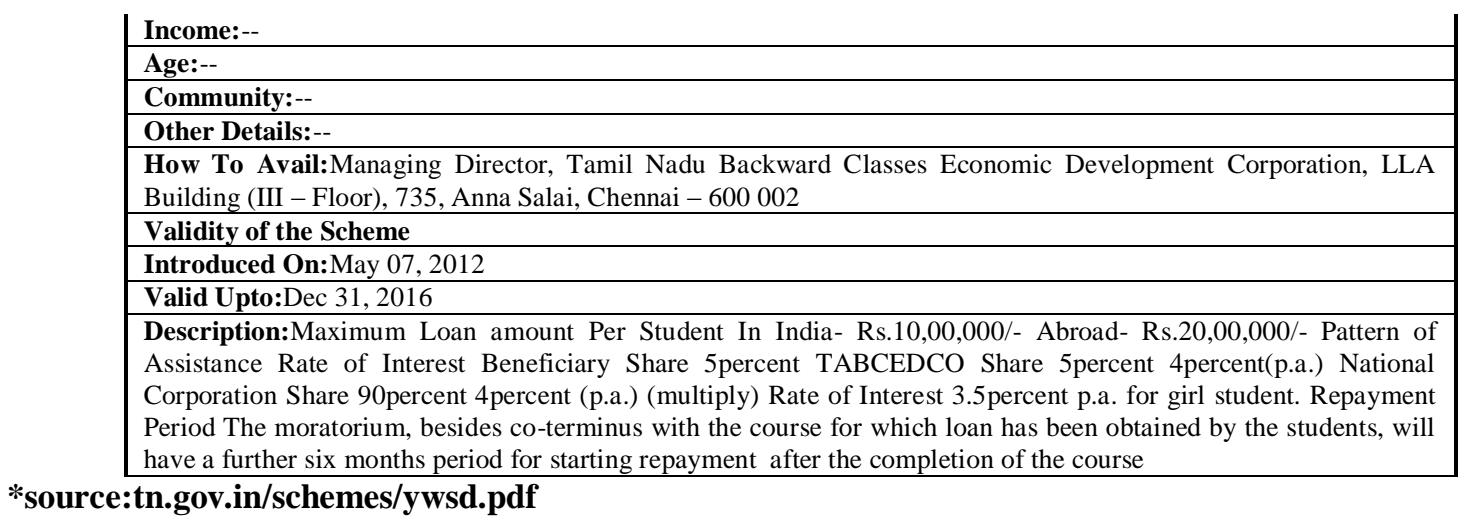

IV. Non Performing Assets

Is defined as a credit facility in respect of which the interest and/or installment of principal has remained 'past due' for a specified period of time. As on 30th Sep 2012, the outstanding amount in educational loan is Rs. 8841 crores (within Tamil Nadu)

\begin{tabular}{|c|c|c|}
\hline \multicolumn{3}{|c|}{ EDUCATION LOANS } \\
\hline Year & $\begin{array}{l}\text { Number of } \\
\text { accounts(lakh) }\end{array}$ & $\begin{array}{r}\text { Balance outstanding } \\
\text { (₹ crore) }\end{array}$ \\
\hline 2010 & 19.12 & $35,292.11$ \\
\hline 2011 & 22.13 & $41,343,81$ \\
\hline 2012 & 23.25 & $45,787,43$ \\
\hline So & aapars & :Data tillMarchoteveryear \\
\hline
\end{tabular}

\section{Literature Review}

K.A. Goyal \& Vijay Joshi (2012) The banking industry in India has a huge canvas of history, which covers the traditional banking practices from the time of Britishers to the reforms period, nationalization to privatization of banks and now increasing numbers of foreign banks in India. Therefore, Banking in India has been through a long journey. Banking industry in India has also achieved a new height with the changing times. The use of technology has brought a revolution in the working style of the banks. R. Srinivasan and Debabrata Das (2011) to study the practices followed in selecting the beneficiary student for grant of education loan for pursuing higher studies in India; problems faced by applicants; background of the problematic borrowers and steps taken to overcome the problems in getting loans. This research paper uses probit model for statistical analysis. However, there does not seem to be any discrimination between students with or without prior work experience, for getting education loan. The study further reveals the reluctance of private sector banks in extending loans. This paper is useful to aspiring students.

\subsection{Statement of Problem}

\section{Research Methodology}

This study is mainly focused on bankers' perspective and the struggle faced by them during the collection of repayment of loans and help India from decrease in number of NPA.

\subsection{Need of the study}

This study is mainly focused on bankers' perspective and the struggle faced by them during the collection of repayment of loans and help India from decrease in number of NPA.

\subsection{Objective of the study}

To study about the problems faced by bankers towards Retrieval of Higher Education Loan provided to students Pursuing professional higher education courses. 


\subsection{Descriptive analysis on sample}

Table 2:Frequency Distribution of Number of students received loan

\begin{tabular}{|l|l|l|}
\hline Number of Students received loan & Frequency & Percent \\
\hline Below 10 & 93 & 17.6 \\
\hline $11-20$ & 160 & 30.3 \\
\hline $21-30$ & 194 & 36.7 \\
\hline Above 30 & 81 & 15.3 \\
\hline Total & 528 & 100.0 \\
\hline
\end{tabular}

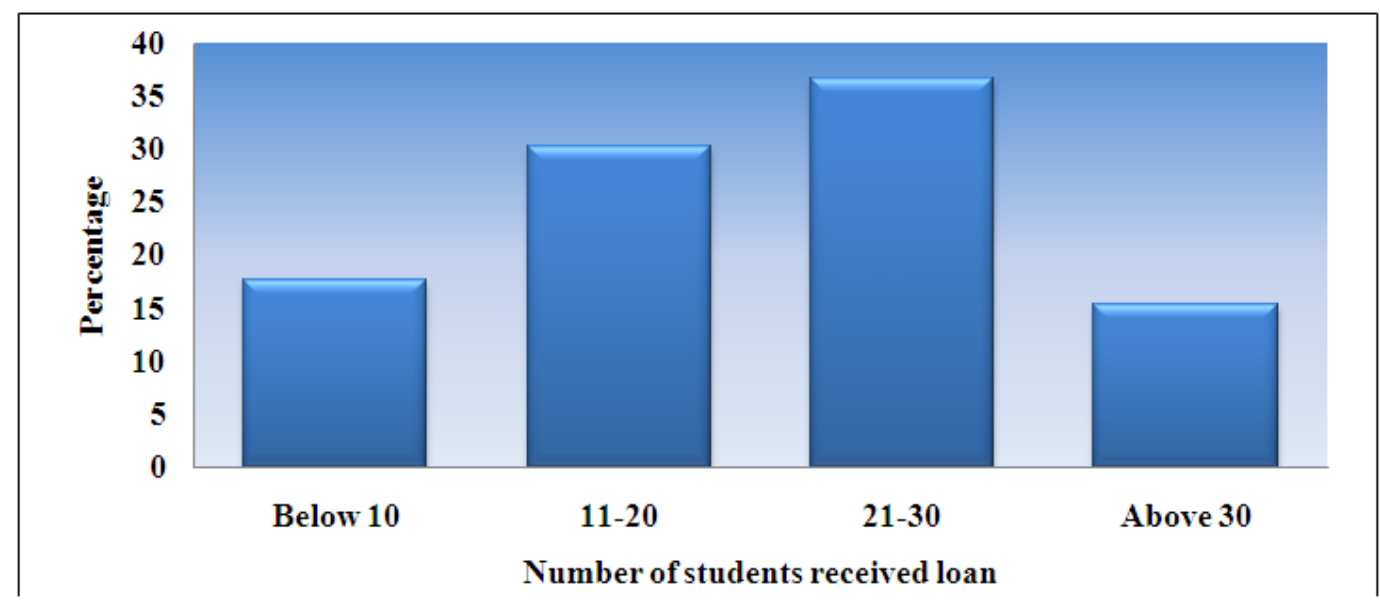

Chart 2: Bar diagram represents Number of students received loan

From the above table 2 explains. 17.6 Percent of the students belong to Below 10, 30.3 Percent of the students belong to 11-20. 36.7 Percent of the students belong to 21-30, 15.3 Percent of the students belong to Above 30. Therefore more number of students who received loan in the category of 21-30. Therefore in the age category of 21-30 many of students are pursing for their higher education and are availing the educational loan through banks

\subsection{Major Hypothesis}

1. There is significant difference between number of students received loan with respect to factors on retrieval of higher education loan.

2. There is positive relationship between various factors involved in retrieval of higher education loan

\subsection{Major Findings}

1. There is significant difference between number of students received loan above 30 have higher problem in repayment of educational loan than below 10 students.

2. The repayment of educational loan is the most important factor influencing Non performing assets.

\section{Conclusion}

Based on the above findings the demographic factors contribute a significant difference towards the factors of non performing assets. Various statistical tools and techniques are applied to find the various inferences and interpretations

\section{References}

[1]. C.R Kothari Research Methodology -Methods \& Techniques-Second Edition (1990)-

[2]. Goyal. K.A and Joshi, V. "A Study of Social and Ethical Issues in banking industry"

[3]. http://www.tn.gov.in/dear/archives/year2008_09/7.\%20Banking.pdf

[4]. http://www.rbi.org.in

[5]. http://www.tn.gov.in/schemes/default.html 